\title{
12. Financial Openness of China and India
}

\author{
Implications for Capital Account Liberalisation
}

Guonan Ma and Robert N. McCauley

\section{Introduction}

In recent years, policymakers in both China and India have announced their intention to further liberalise their still heavily managed capital accounts. The world has a huge stake in China and India integrating their finances into global markets without disruptive spillovers to the global financial markets (Hooley 2013). This is all the more true for China, which is larger and more willing to undertake incremental capital account liberalisation over the coming years.

The extent to which these economies have already become financially integrated with the rest of the world serves as a practical starting point for policymakers managing the task of further capital opening, by indicating potential challenges and attendant risks. A starting point of considerable integration would suggest that China and India have little to lose and much to gain if the opening serves to force the pace of domestic financial liberalisation. Little financial integration, however, would indicate greater risks and larger required adjustments in the domestic economy and markets in response to capital opening.

Much analysis of capital account openness uses the Chinn-Ito (2008) index, an interval, de jure measure derived from four on-off variables in the IMF's Annual Report on Exchange Arrangements and Restrictions (Figure 12.1, left-hand panel). For de facto openness, 'the most widely used measure' (IMF 2010:51) is the ratio of the sum of international assets and liabilities to GDP (Lane and Milesi-Ferretti 2003, 2007) (Figure 12.1, right-hand panel).

1 Guonan Ma is a visiting fellow at Bruegel and Robert McCauley is a senior adviser, Monetary and Economic Department, Bank for International Settlements (BIS). We wish to thank Claudio Borio for comments and Bat-el Berger and Tracy Chan for their excellent research assistance. This chapter is partially based on Ma and McCauley (2013). Views expressed are those of the authors and not necessarily those of the BIS. 

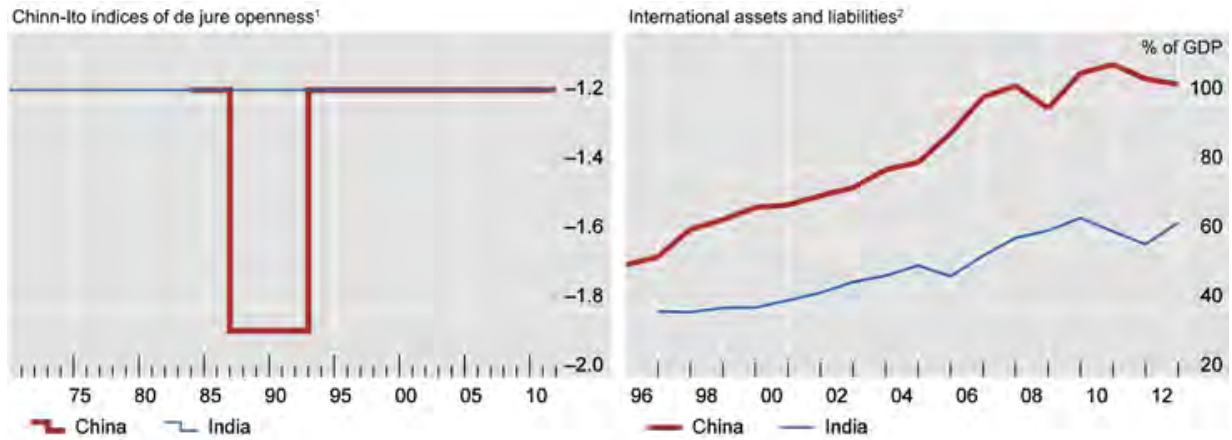

Figure 12.1 Capital Account Openness of China and India: De Jure and De Facto Measures

${ }^{1}$ It is based on the binary dummy variables that codify the tabulation of restrictions on cross-border financial transactions reported in the IMF's Annual Report on Exchange Arrangements and Exchange Restrictions (2010). For further details, see Chinn and Ito (2006).

${ }^{2}$ International investment position. Data for China before 2004 from Lane and Milesi-Ferretti (2007).

Sources: The IMF's International Financial Statistics (<http://www.econdata.com/databases/imf-andother-international/ifs/>) and World Economic Outlook (<http://www.imf.org/external/pubs/ft/weo $>)$.

We question whether these measures appropriately track the progress and relative position of China and India on the road to international financial integration. ${ }^{2}$ We disagree with Chinn-Ito that China and India are both stalled on the road and agree with Lane and Milesi-Ferretti that both are often moving forward - that is, opening up. Admittedly, the process sometimes can be two steps forwards and one step back. Moreover, we question whether Chinn-Ito (tied) or Lane and Milesi-Ferretti (China ahead) have their relative position right, at least on average for the past decade.

We also question an emerging consensus regarding implications of capital opening for capital flows. Both He et al. (2012) and Bayoumi and Ohnesorge (2013) argue that when China fully opens up its capital account, there will be not only larger external positions, but also, on balance, larger net private assets. By contrast, Bayoumi and Ohnesorge (2013) expect India to experience little net private capital outflows. Neither study considers stocks of bank assets, which are inherently difficult to model. Our findings on the pricing of the three financial instruments onshore and offshore raise questions about this consensus, since relative prices would encourage bank inflows. In particular, our finding that in China money-market instruments are cheap onshore leaves us concerned that these baseline projections that neglect bank assets are missing the potential for huge short-term inflows. 
We raise these questions based on an examination of three de facto pricebased measures. For currency forwards, short-term interest rates and equity prices, we analyse average deviations from the law of one price. The basic idea is that, other things being equal and under normal market conditions, onshore and offshore prices of the same underlying financial instrument should be about the same, if capital is mobile. Also, we offer cross-country benchmarks as well as bilateral comparisons as a gauge of the remaining challenge of the capital account opening task. Finally, we look at the signs of these price gaps to see whether each financial instrument is priced more cheaply onshore or offshore, which can serve as signals of positive pressures from inward or outward private capital flows, respectively.

We advance four hypotheses, two in the time series (ts) and two in the crosssection (xs), and subject them to the evidence of the past decade: 2003-13.

- Hts1: Lane and Milesi-Ferretti are right: both China and India are opening.

- Hxs1: Chinn-Ito and Lane and Milesi-Ferretti are wrong: India is more open than China.

- Hts2: Both China and India remain some distance from financial openness.

- Hxs2: China faces net inflow pressures in the short term, while India may face more balanced outflows and inflows when opening up.

The chapter is organised as follows. Sections two to four present evidence on the three measures of onshore-offshore price gaps for foreign exchange forwards, money-market yields and stock-market prices. Section five draws on the evidence on price gaps to explore implications for China's capital opening, while the final section concludes.

\section{Onshore and offshore foreign exchange forwards}

We first contrast forward foreign exchange rates in Shanghai or Mumbai with those traded offshore in Hong Kong, Singapore or Tokyo. Capital mobility tends to equalise onshore and offshore forward rates. Thus, the currency with smaller differences in rates at home and abroad is more financially open. We define crossborder price gaps so that a positive value indicates that contracts are cheaper onshore. For currency forwards, a positive gap means that a dollar fetches more renminbi or rupee in Shanghai or Mumbai than offshore. For money markets, a positive gap means that prices are lower (yields higher) in Shanghai or Mumbai than offshore. For equities, a positive gap means shares are cheaper onshore. 
As Liu and Otani (2005) argued, this measure benefits from using directly observed prices; but our comparison can only start when China inaugurated its onshore forward currency market in 2003. Since traders can access the domestic forward currency market only on the basis of 'real demand' - that is, underlying transactions backed by trade documents - domestic forward rates can differ from those in the offshore non-deliverable market, where allcomers can transact. ${ }^{3}$

We define the onshore-offshore forward currency gap as in Equation 12.1.

Equation 12.1

Forward currency gap ga $\left._{t}-\mathrm{FDF}_{\mathrm{t}}\right) / \mathrm{S}_{\mathrm{t}}$

In Equation 12.1, $\mathrm{F}_{\mathrm{t}}$ is the onshore forward; $\mathrm{NDF}_{\mathrm{t}}$ is the non-deliverable offshore forward; and $S_{t}$ is the onshore spot exchange rate-all expressed as domestic currency per US dollar. A positive forward premium gap indicates the respective currency is cheaper - that is, priced for less appreciation or more depreciation - onshore than offshore. This in turn would be likely to attract more inflows than outflows when the capital account opens up.

Figure 12.2 strikes the eye with how both currencies became cheap offshore after the Lehman failure, both at the three-month (left-hand panel) and the 12-month (right-hand panel) tenor. It is also striking how expensive the longer forward of the renminbi used to be offshore, where speculators paid up in anticipation of its move from 8.2 to 6.1 per dollar. Also observe the sharp widening in the onshore/offshore foreign exchange forward gaps during the GFC, probably because of the market dislocations to be discussed below. Both the sign and the size of the forward gaps for the renminbi and rupee correlate substantially, possibly suggesting that some global factors such as the sentiment of global investors and market uncertainties may play a meaningful role in the evolution of the forward gaps.

Table 12.1 confirms that over the past decade, 2003-13, the average of the forward gap for the renminbi is clearly larger than that of the rupee. Hence the forward markets onshore and offshore have been more segmented for the renminbi than for the rupee, for both three-month and 12-month tenors, and for both the pre-crisis and the post-crisis periods. In this sense, India is financially more integrated with the global financial market than is China.

The dynamics of their forward premium gaps have, however, been quite different before and after the GFC. In particular, for both tenors, the onshoreoffshore forward currency gaps of the renminbi have narrowed noticeably since

3 On NDFs, see Ma et al. (2004); Misra and Behera (2006); Ma and McCauley (2008a, 2008b); and McCauley et al. (2014). 
the crisis, suggesting that China has become more open financially over recent years. Not so for India, which has witnessed wider forward premium gaps since the GFC. One possible reason could be the Chinese Government's promotion of external use of the renminbi, facilitating cross-border arbitrage. Another could relate to the emerging market sell-off in the wake of the expected US Federal Reserve's tapering signal mostly in the third quarter of 2013, which most hurt deficit emerging economies. Of course, one can ask why this last particular shock was so asymmetric and different for the renminbi and the rupee (Ma and McCauley 2013; McCauley et al. 2014).

Moreover, while the renminbi is priced more cheaply onshore than offshore in the foreign exchange forward markets in all cases, the Indian rupee forward is mostly more expensive onshore in most cases. This holds true for both the full sample and the pre and post-crisis periods. In other words, when the capital account opens up, the renminbi will most likely face appreciation and net private capital inflow pressures, while the rupee may endure some depreciation and net private outflow pressures. Even the adjustments can take place mainly through positioning rather than actual cross-border flows; expectations may bias broader gross private capital inflows in case of a cheaper currency in the onshore forward market.

On balance, trading of currency forwards suggests India has been more financially open than China over the past decade, more so for the pre-crisis period than the post-crisis period, though China is catching up faster and noticeably narrowing India's lead since the GFC. Upon capital opening, China may see stronger private capital inflow pressures than India does, other things being equal.

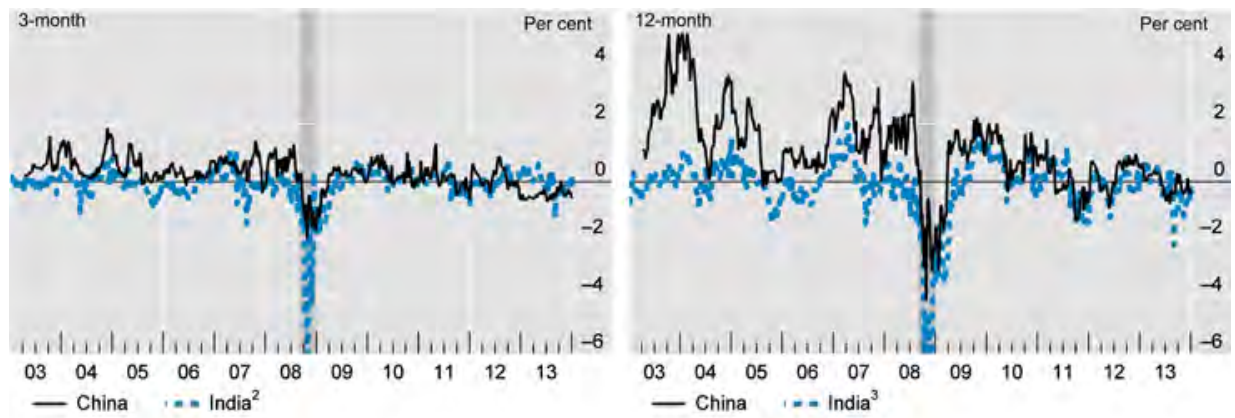

Figure 12.2 Onshore Foreign Exchange Forward Less Offshore Non-Deliverable Forwards (as percentage of spot rate)

${ }^{1}$ Shaded area indicates the GFC period of September-December 2008.

${ }^{2}$ Minimum at -7.88 per cent on 24 October 2008.

${ }^{3}$ Minimum at -11.7 per cent on 24 October 2008.

Sources: Bloomberg; CEIC. 
If currency forwards suggest that India has remained more open than China on average over the past decade, albeit with a shrinking lead, how far do they have to go in terms of capital account liberalisation? The euro/dollar trades, except in the most extreme markets, at the same rate in Frankfurt and in New York. Among currencies with a non-deliverable forward (NDF), the Korean won has the biggest and most integrated market. Post crisis, the rupee forward gap is between that of the won and a benchmark of six other NDF currencies for both tenors (Table 12.1). By contrast, the larger average absolute values for the renminbi are close to a benchmark of six other NDF currencies and point to weaker arbitrage and thus a longer way to go in capital opening.

Table 12.1 Onshore Less Offshore Foreign Exchange Forward Premiums (percentage of the spot)

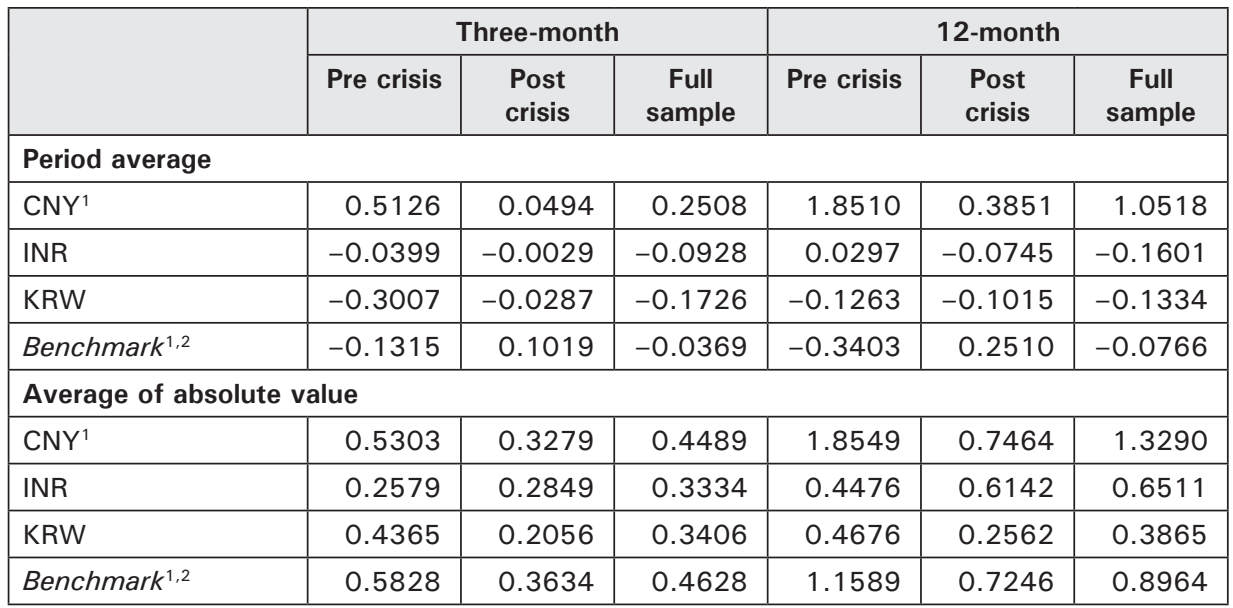

${ }^{1}$ Data start 7 April 2003 for renminbi, 7 January 2004 for Colombian peso, 12 January 2012 for Russian rouble.

${ }^{2}$ Benchmark averages Brazilian real, Colombian peso, Indonesian rupiah, Philippine peso, Russian rouble and Taiwanese dollar.

Sources: Bloomberg; Reuters.

Note: Daily data of forward premium gap are calculated as the difference between onshore forward and offshore non-deliverable forward as a percentage of spot price. Closing at Tokyo 8 pm for Asian currencies; at London 6 pm for Russian rouble; at New York 5 pm for Brazilian real and Colombian peso. The full sample period is between 6 January 2003 and 31 December 2013; the crisis period is between September and December 2008. 


\section{Onshore and offshore short-term interest rates}

We next compare short-term yields onshore and offshore. Otani and Tiwari (1981) compared yen yields in Tokyo and offshore, and Frankel (1992) prescribed such comparisons to test for capital mobility. Prior to the expansion of the offshore renminbi market in 2010, we do not observe offshore yields for both currencies; rather we infer yields from NDFs, assuming they are priced off dollar Libor - a reasonable assumption before the GFC. ${ }^{4}$

\section{Equation 12.2}

$$
\left.\mathrm{NDF}_{t}=\mathrm{S}_{\mathrm{t}}\left(1+\mathrm{i}_{\mathrm{t}}\right) /\left(1+\mathrm{r}_{\mathrm{t}}\right)\right)
$$

In Equation 12.2, $\mathrm{i}$ is the implied offshore interest rate on the home currency and $r_{t}{ }_{t}$ dollar Libor. Rearranging terms, we extract the implied offshore interest rate (Equation 12.3).

\section{Equation 12.3}

$$
i_{t}=N_{t}^{*}\left(1+r_{t}^{\$}\right) / S_{t}-1
$$

The onshore-offshore money yield gap is defined as $\left(r_{t}-i_{t}\right)$, where $r_{t}$ is the directly observed onshore three-month bank rate or a 12-month government bill rate. If $\left(r_{t}-i_{t}\right)$ differs significantly from zero, the offshore market is segmented from the onshore. A positive money yield gap indicates that money-market instruments are priced cheaper (yield more) onshore than offshore. A smaller mean of the absolute yield gap points to greater financial openness.

Money-market yield gaps have narrowed somewhat for both economies in the 2000s (Figure 12.3). Ma et al. (2004) and Kohli (2011) found that this happened for the rupee in the early 2000s. The renminbi gap has narrowed since the GFC, but the rupee gap has widened instead. Again, we observe noted co-movements in the yield gaps of the renminbi and rupee, indicating possible important global drivers in addition to local impediments.

4 The GFC broke down covered interest parity (Baba and Packer 2009), observationally equivalent to pervasive capital controls. With a global 'dollar shortage' (McGuire and von Peter 2009), US dollar Libor cannot safely be inserted into Equation 12.3. Mancini and Ranaldo (2011) test interest rate parity without Libor. If dollar yields were equal onshore and offshore, and forwards were priced off interest differentials, our yield gaps would simply be transformations of the forward gaps above. But onshore dollar yields can and do deviate from offshore levels. 

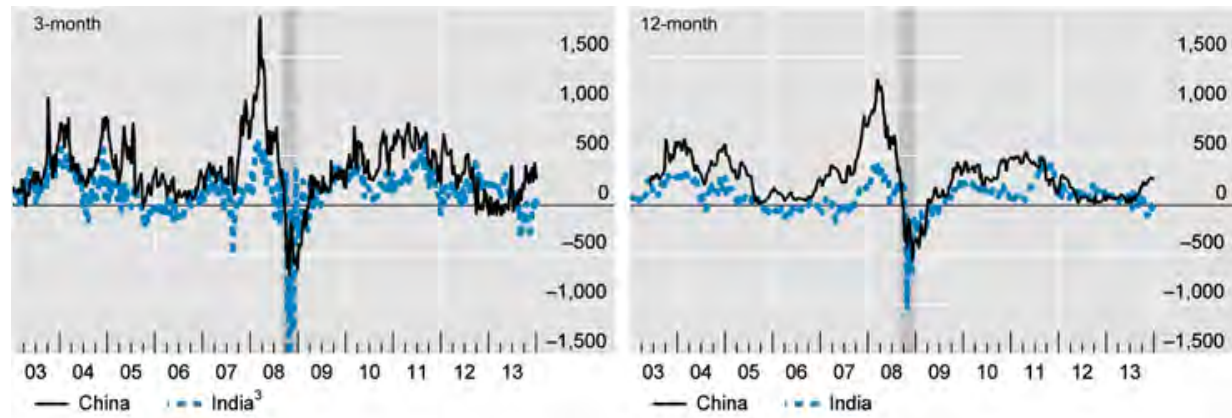

Figure 12.3 Onshore Money-Market Yield Less Offshore NDF-Implied Yield (in basis points)

Sources: Bloomberg; CEIC.

Notes: Weekly data. For China: three-month (12-month) NDF, three-month Chibor (one-year PBC bill auction yield before July 2008; secondary market yield thereafter), and three-month (12-month) Libor. For India: three-month (12-month) NDF, three-month Mumbai interbank offer rate (364-day Treasury Bill implicit yield), and three-month (12-month) Libor. Shaded area indicates the GFC period of SeptemberDecember 2008. Minimum at -3310.89 bps on 24 October 2008.

In sum, most of the main findings for the foreign exchange forward gap also hold in the case of the money yield gap. Each and every pairwise comparison strongly suggests that over the past decade, cross-border arbitrage continued to have freer play in India to keep yields in line (Table 12.2). On balance, onshore and inferred offshore money rates, like trading of currency forwards, identify India as more financially open than China over the past decade, for the full sample, the pre-crisis period and the post-crisis period, though its lead has been narrowing. More interestingly, again, the post-crisis yield gap of the rupee has widened over the pre-crisis counterpart, while that of the renminbi has narrowed considerably and is rapidly converging with the rupee gap in the wake of the GFC. On this measure, China again is catching up in terms of financial openness.

One main difference between the currency forward and money-market instruments is that for both currencies, money-market instruments have been cheaper onshore than offshore, indicating potentially greater private capital inflows than outflows, at least under money-market instruments, once their capital accounts open further.

Again, the benchmark won suggests that both renminbi and rupee money remain some distance from high financial integration. In particular, onshore and offshore rupee yields remain further apart than their won counterparts even though the won gaps also widened after the crisis (and before the crisis relative to 2003-04) (Ma et al. 2004:90). If the rupee has a way to go, the renminbi has still further, but apparently the renminbi is catching up rapidly, while after the crisis, the rupee appears to have stepped back and is gradually losing its lead. 
Table 12.2 Onshore Money-Market Yield Less Offshore NDF-Implied Yield (in basis point)

\begin{tabular}{|l|r|r|r|r|r|r|}
\hline \multirow{2}{*}{} & \multicolumn{3}{|c|}{ Three-month } & \multicolumn{3}{c|}{ 12-month } \\
\cline { 2 - 7 } & Pre crisis & $\begin{array}{c}\text { Post } \\
\text { crisis }\end{array}$ & $\begin{array}{c}\text { Full } \\
\text { sample }\end{array}$ & Pre crisis & $\begin{array}{c}\text { Post } \\
\text { crisis }\end{array}$ & $\begin{array}{c}\text { Full } \\
\text { sample }\end{array}$ \\
\hline Period average & 436.8 & 316.1 & 354.7 & 381.1 & 208.2 & 280.1 \\
\hline CNY & 148.0 & 181.5 & 146.3 & 101.5 & 107.7 & 95.0 \\
\hline INR & 49.5 & 105.2 & 90.6 & 67.2 & 98.9 & 89.2 \\
\hline KRW & 437.0 & 345.3 & 392.7 & 381.1 & 235.4 & 308.9 \\
\hline Average of absolute value & 192.7 & 212.9 & 215.2 & 132.1 & 138.4 & 141.1 \\
\hline CNY & 76.6 & 113.8 & 111.6 & 68.5 & 99.5 & 90.7 \\
\hline INR & \multicolumn{7}{|l|}{} \\
\hline KRW & \multicolumn{7}{|l|}{} \\
\hline
\end{tabular}

Sources: Bloomberg; CEIC.

Notes: Daily data. For China: three-month (12-month) NDF, three-month Chibor (one-year PBC bill auction yield before July 2008; secondary market yield thereafter), and three-month (12-month) Libor. For India: three-month (12-month) NDF, three-month Mibor (364-day Treasury Bill implicit yield), and three-month (12-month) Libor. For Korea: three-month (12-month) NDF, three-month certificate of deposit rate (oneyear Treasury Bond yield in the secondary market), and three-month (12-month) Libor. The full sample period is between 27 May 2003 and 31 December 2013; the crisis period is between September and December 2008.

\section{International integration of equity markets}

The Chinese and Indian authorities have also run natural experiments by allowing firms to list their shares on exchanges both in Shanghai or Mumbai and in Hong Kong or New York. Onshore and offshore trades take place in different currencies, but a free flow of capital would ensure only minor differences in prices. Deviations from the law of one price point to markets segmented by official limits on foreign shareholdings in domestic markets. Following LevyYeyati et al. (2009), we analyse the difference between onshore and offshore share prices and the speed of their convergence.

We construct indices of shares that are cross-listed in Shanghai, Hong Kong and New York, on the one hand (Peng et al. 2008), and Mumbai and New York on the other. We weigh individual share price differentials by market capitalisations in Hong Kong and Mumbai. We define the price gap as the ratio of the offshore to onshore prices: a ratio greater than 100 indicates the share trades cheaper onshore than offshore. The closer this 'cross-market price premium' is to 100, the higher is the degree of onshore and offshore equity markets. Our Chinese index in Figure 12.4 resembles the commercial 'Hang Seng China AH [A: Shanghai; H: Hong Kong] Premium Index' (Ma and McCauley 2013). 
A threshold observation is that the line for India lies above 100, while the lines for China lie below 100. Indian shares tend to be cheaper onshore. By contrast, Chinese shares trade at a premium in Shanghai over their prices in Hong Kong or New York. Chinese investors wish they could buy Chinese equities at Hong Kong or New York prices. Thus, the more expensive share prices in Shanghai would likely prompt more private outflows than inflows, once restrictions on the capital account are further removed. The opposite is true for India. Nevertheless, by late 2013, the Shanghai premium and Mumbai discount had largely vanished. Indeed, the Chinese equity market integration has come a long way and appeared to even have taken a small lead over India's by 2013 .

Table 12.3 confirms that price differentials have tended to narrow since the GFC. Before the crisis, Indian shares in New York traded at a 30 per cent premium, while Chinese shares in Hong Kong traded at a discount of more than 45 per cent. After the crisis, the New York premium narrowed to less than 10 per cent for Indian companies and the Hong Kong discount to some 20 per cent for Chinese companies. So India managed to sustain the financial opening in the equity market, contrasting the back-stepping seen for the two fixed-income markets.

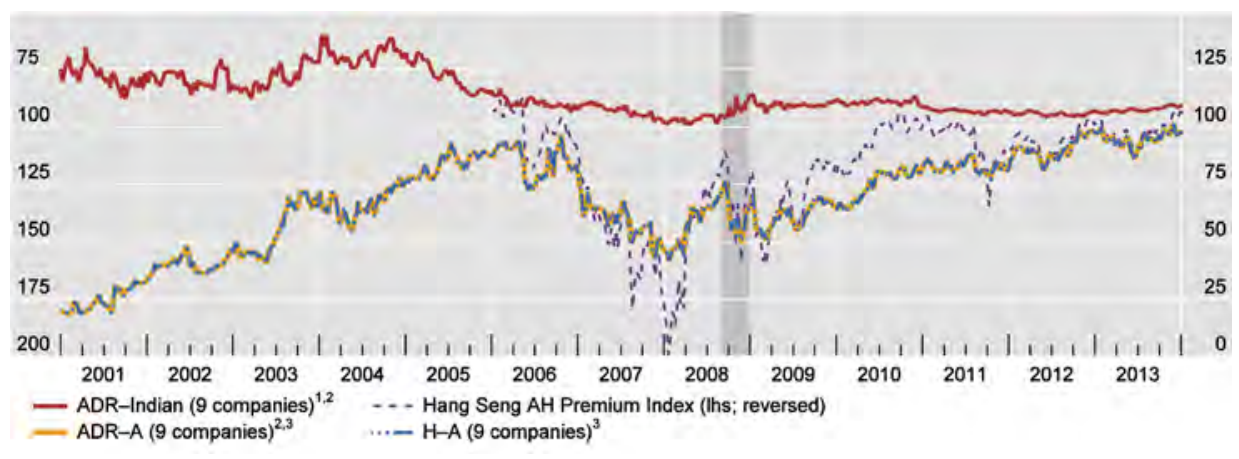

Figure 12.4 Ratios of Overseas Share Prices to Equivalent Local Share Prices (per cent, weekly average)

${ }^{1}$ Average of ICICI Bank, Wipro, Dr Reddy's Laboratories, HDFC Bank, Sterlite Industries (India) (until August 2013), Mahanagar Telephone Nigam, Tata Motors, Tata Communications and Infosys Technologies weighted by their domestic market capitalisation.

${ }^{2}$ Ratio of Asian closing to New York opening on the same day.

${ }^{3}$ Average of China Eastern Airlines, China Life Insurance, China Petroleum and Chemical, China Southern Airlines, Guangshen Railway, Huaneng Power International, Sinopec Shanghai Petrochemical, Aluminum Corporation of China and Petro China weighted by their Hong Kong market capitalisation. Shaded area indicates the Global Financial Crisis of September-December 2008.

Sources: Bloomberg; authors' calculations. 
While for the full sample of 1999 and 2013, the Indian equity market is much more internationally integrated than that of China, it still has a long way to go when measured against the close alignment of prices of Chinese shares in Hong Kong and New York. Similarly, the Indian equity market has a way to go when compared with the sample 0.12 per cent mean difference between onshore and offshore share prices for a sample of emerging markets in Levy-Yeyati et al. (2009:441).

Table 12.3 Ratios of Overseas Share Prices to Local Share Prices and Convergence Speed

\begin{tabular}{|c|c|c|c|c|c|}
\hline & $\begin{array}{c}\text { H-A ratio } \\
41 \text { dual- } \\
\text { listed } \\
\text { companies }\end{array}$ & $\begin{array}{c}\text { H-A ratio } \\
9 \text { triple- } \\
\text { listed } \\
\text { companies }\end{array}$ & $\begin{array}{l}\text { ADR-A ratio } \\
9 \text { triple- } \\
\text { listed } \\
\text { companies }\end{array}$ & $\begin{array}{l}\text { ADR-H ratio } \\
9 \text { triple- } \\
\text { listed } \\
\text { companies }\end{array}$ & $\begin{array}{l}\text { ADR-India } \\
\text { ratio } \\
9 \text { dual-listed } \\
\text { companies }\end{array}$ \\
\hline \multicolumn{6}{|c|}{ Period average $(\%)^{1,2}$} \\
\hline Pre crisis & 53.10 & 53.30 & 53.30 & 99.89 & 128.89 \\
\hline Post crisis & 87.67 & 79.99 & 79.93 & 99.98 & 108.07 \\
\hline Full sample & 64.91 & 62.29 & 62.25 & 99.91 & 121.64 \\
\hline \multicolumn{6}{|c|}{ Estimated half-life (days) ${ }^{2,3}$} \\
\hline Pre crisis & 255 & 125 & 111 & 1 & 35 \\
\hline Post crisis & 109 & 213 & 162 & 1 & 13 \\
\hline Full sample & 259 & 174 & 142 & 1 & 49 \\
\hline
\end{tabular}

${ }^{1}$ Ratio of overseas share price to equivalent local share price for cross-listed companies; weighted average based on Hong Kong market capitalisation for China and at domestic capitalisation for India. See Figure 12.6 for further information.

${ }^{2}$ The full sample period is between 15 March 1999 and 31 December 2013; the crisis period is between September and December 2008.

${ }^{3}$ Based on estimation of Equation 12.4 in the text; see Annex 1 for details.

Sources: Bloomberg; authors' estimations.

Table 12.3 also reports estimates of the half-life of the convergence of onshore and offshore share prices to their centres of gravity for the periods before and after the crisis. This half-life is estimated from Equation 12.4 (Peng et al. 2008).

\section{Equation 12.4}

$$
\Delta \mathrm{q}_{\mathrm{i}, \mathrm{t}}=\alpha+\beta \mathrm{q}_{\mathrm{i}, \mathrm{t}-\mathrm{l}}+\Sigma \varphi_{\mathrm{n}} \Delta \mathrm{q}_{\mathrm{i}, \mathrm{t}-\mathrm{n}}+\varepsilon_{\mathrm{i}, \mathrm{t}}
$$

In Equation 12.4, $\mathrm{q}_{\mathrm{i}, \mathrm{t}}$ is the logarithm of the overseas-local share price ratio for the cross-listed companies; $\Delta$ is the first difference operator. Since the estimated $ß<0$, the speed of convergence, or half-life of a shock, to the premium can be taken as $-\ln (2) / \ln (1+\beta)$. Table 12.3 shows mixed results, though for both the Chinese and the Indian markets, the half-life fell in half of the cases after the GFC, indicating more integration (Ma and McCauley 2013). Again on this measure, the Chinese equity market on average remained three to five times 
more segmented than the Indian equity market. In contrast to the instantaneous arbitrage between New York and Hong Kong, ${ }^{5}$ that between New York and Mumbai takes weeks and that between Hong Kong and Shanghai takes months.

\section{Implications for capital account opening}

In this section, we draw implications from our findings of price gaps for capital account opening, focusing on China's case. Studies of the likely profile of China's international assets and liabilities over the medium term given capital account opening highlight the scope for net private outflows of portfolio and direct investment. On direct investment, China's longstanding welcome for foreign companies contrasts with the quite recent adoption of the policy to encourage outward direct investment, particularly in commodity production. Limits on outward portfolio investment were eased just before the GFC and to this day the limits do not bind; but the upshot is that private portfolio claims on the rest of the world's stocks and bonds remain low, and the potential increase appears huge as the capital account opens up and the income level rises.

He et al. (2012) and Bayoumi and Ohnsorge (2013) present reasonable medium-term outlooks for a rise in net private external assets in the event of a full capital account liberalisation in China. Both project big increases in gross positions, assets and liabilities alike, and both predict private assets would increase more than liabilities. Thus, both foresee that China can be expected to experience net private capital outflows following thorough capital account liberalisation. Such net outflows would not necessarily put downward pressure on the renminbi's value if the current account remains in surplus, or if offset by a policy of a drawdown of the sizeable official reserves.

There are some differences between these exercises. He et al. (2012) examine both direct investment and portfolio stocks, and their result is driven by the legacy of asymmetric capital controls (with acquisition of external assets by private Chinese more tightly controlled, especially in direct investment), financial market development in China and higher growth there. They project a larger step-up in direct investment net assets of 10 per cent of GDP than that in net portfolio assets, of 8 per cent of GDP (Table 12.4). Bayoumi and Ornsorge (2013) analyse portfolio stocks only and find the increase in net private assets could result from an increase in gross portfolio assets of 10-25 per cent of GDP

5 Or a sample average of one to two days for emerging markets in Levy-Yeyati et al. (2009:444). 
and gross liabilities of 2-10 per cent of GDP (Table 12.4). The resulting increase in net portfolio assets of 11-18 per cent of GDP exceeds the 8 per cent estimate of He et al. (2012). ${ }^{6}$

Table 12.4 Impact of Capital Account Liberalisation in China on Direct and Portfolio Investment (stock adjustment as percentage of GDP)

\begin{tabular}{|l|c|c|c|c|}
\hline & \multicolumn{2}{|c|}{ Bayoumi \& Ornsorge (2013) } & He et al. (2012) & $\begin{array}{c}\text { Memo: Actual } \\
\text { I 2020 }\end{array}$ \\
\cline { 2 - 3 } & & $\begin{array}{c}\text { Adjusted } \\
\text { for smaller } \\
\text { domestic stocks }\end{array}$ & & \\
\hline FDI assets & & & 21.6 & 5.3 \\
\hline FDI liabilities & & & 11.2 & 25.1 \\
\hline Net FDI & & $9.4-15.1$ & 10.4 & -19.8 \\
\hline Portfolio assets & $15.4-24.9$ & $1.7-9.9$ & 16.4 & 4.3 \\
\hline Portfolio liabilities & $1.7-9.9$ & $4.1-8.2$ & 7.7 & 3.8 \\
\hline Net portfolio & $10.7-8.1$ & & & 0.6 \\
\hline
\end{tabular}

Sources: Bayoumi and Ornsorge (2013:28); He et al. (2012:29).

Policymakers, however, have to be concerned about not only the mediumterm resting place or steady state, but also the dynamic path, as well as the volatility realised along it. Both papers neglect the banking flows, which can be huge and volatile. This is understandable, since the cross-country pattern of external bank assets and liabilities is hard to account for in standard modelling exercises.

Moreover, these exercises based on stocks of financial assets and liabilities do not allow prices themselves to be a major driver of both portfolio and banking flows in the short term. Our evidence on the onshore/offshore price gaps may help shed light on possible short-term dynamics of capital flows upon full capital account liberalisation. In brief, we find that the inflow pressure in the money market is very strong in China, in sharp contrast with the medium-term prospect for portfolio and direct investment outflows.

6 If the domestic equity market is adjusted for untraded shares and the domestic bond market is adjusted for bank-held bonds then Bayoumi and Ornsorge (2013) put the stock adjustment at only 4-8 per cent of GDP. Any such projected net portfolio outflows or build-up in net private external assets could easily be accommodated by the official sector running down the large foreign exchange reserves resulting in a rebalancing between private and public portfolios. The privatisation of China's foreign assets should be seen as a natural consequence of allowing the private sector greater scope to buy foreign stocks and bonds (Ma and McCauley 2014). 
In particular, we have shown that the binding capital controls allow differences in forward exchange rates onshore and offshore, and also in onshore and offshore short-term interest rates. These price gaps tend to favour net private capital inflows rather than outflows, since the price of the same financial instrucment is lower onshore than offshore.

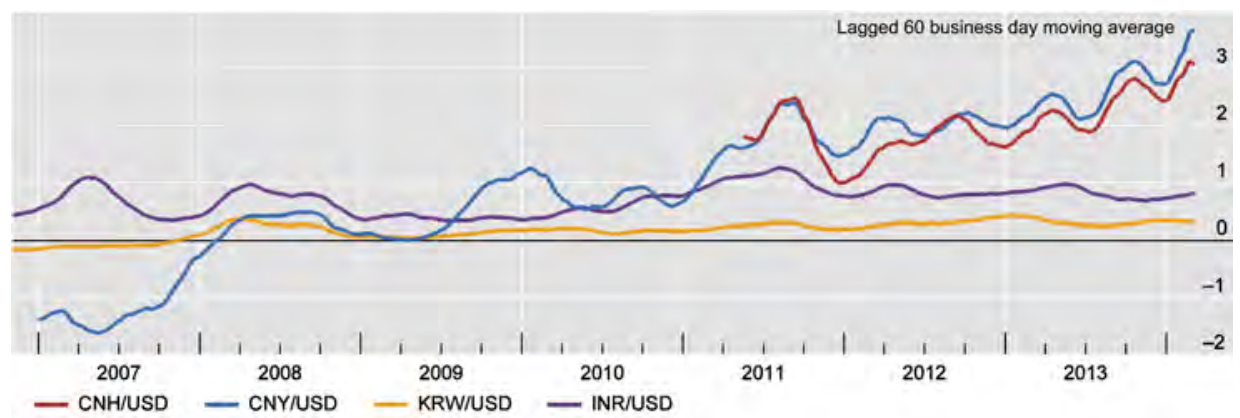

Figure 12.5 Sharpe Ratios

Source: Bloomberg and BIS staff calculations.

Note: Defined as the three-month interest rate differential (Shibor for renminbi, Mibor for rupee, 91-day certificate of deposit for won and Libor for dollar) divided by the implied volatility derived from threemonth at-the-money exchange rate options for the relevant currency pair.

Moreover, the portfolio inflow pressure can be seen more clearly by consulting an ex ante measure of the risk-adjusted return on money-market carry trades. We take the short-term interest rate differential as a ratio of shortterm volatility implied in currency options - a simple version of the Sharpe ratio. Figure 12.5 shows how attractive an open Chinese money market would be at recent levels of currency volatility. With three-month Shibor at 5 per cent and Libor at 0.25 per cent and the implied volatility of the renminbi at less than 2 per cent, non-residents would be strongly attracted to the Chinese money market.

Indeed, our simple Sharpe ratio for the renminbi averages 3.5 in recent months, compared to a range of 0.3 to 0.8 for other major emerging market currencies shown in Figure 12.5. Thus, the renminbi clearly represents an extremely attractive target among all the major emerging-market currencies for carry traders, suggesting substantial pressures from inward bank and bond flows into China, at least in the short term. Even the increase in implied volatility associated with the mild renminbi depreciation around the widening of the renminbi daily trading band in mid March 2014 left the carry-to-risk ratio very attractive (see below). ${ }^{7}$

7 Note that in contrast, although India's money-market rates at 8 per cent are much more attractive taken in isolation, when the volatility of the rupee/dollar rate is factored in, the carry is not so attractive. 
We have illustrated the strong incentives for fixed income inflows at the three-month tenor, but the problem extends out the yield curve, albeit to a lesser extent. That is, the Chinese Government's yields exceed the US Government's yields all the way out to 10 years and beyond. Since the Chinese yield curve is on the flat side, the yield gap narrows with maturity.

Near-term developments will not necessarily lessen the attraction of the Chinese money market. While the normalisation of US dollar rates would tend to narrow the gap with Chinese yields, the liberalisation of interest rates in China is expected to widen it. He et al. (2014) use a variety of approaches to conclude that equilibrium yields in China could be 2.5-3 per cent higher from the current regulated level. Such a rise would take the Chinese yield curve to 5-6 per cent at the short end and 6-7 per cent at the long end. On the US side, Laskey and Whalen (2014) of the Congressional Budget Office project that the US Federal Reserve will take short-term rates up to 3.5 per cent later in this decade while 10-year Treasury yields will rise to 5 per cent. How precisely these two yield curves will relate to each other as normalisation and liberalisation play out is difficult to predict; but pressure from inward capital flows, especially at the short end, is a serious near-term prospect in light of a more liberal Chinese capital account. Thus, while domestic financial liberalisation is often considered a prerequisite for further external financial opening, it can add to its immediate challenges.

Our findings yield two useful insights for Chinese policymakers managing capital account liberalisation. First, the contrast between our short-term inflow pressures and the consensus medium-term outflow pressures could potentially imply volatility along the path towards full capital account openness. Policymakers need to carefully negotiate this risk-laden process. Ocampo and Erten (2014) suggest Chinese policymakers could first suspend the existing capital controls as a way to open up the capital account, without scrapping all the underlying institutional arrangements and control tools. At least, stronger and more transparent reporting and statistical systems could be put in place so that broad market positions and cross-border flows can be tracked in a timely and systematic fashion.

Second, a sustained increase in exchange rate variability ahead of substantial capital opening could serve to render the renminbi a less attractive carry-trade target. The PBC's widening of the permitted daily trading band from \pm 1 per cent to \pm 2 per cent in March 2014 clearly worked in this direction: the Sharpe ratio for the renminbi more than halved. More exchange rate risk would help tip the balance from short-term inflow pressure to medium-term outflow pressures. 


\section{Summary}

In this conclusion, we recap the evidence bearing on our four hypotheses and draw implications.

First, both the Chinese and the Indian economies are opening up. Our price evidence clearly questions the relevance and usefulness of the Chinn-Ito indices of de jure controls. Advancing financial integration is allowing policymakers to gain both experience and confidence, facilitating rather than impeding an acceleration of desired capital account liberalisation.

Second, India is more open than China. Thus we challenge Chinn and Ito's index, which suggests that China and India restrict capital flows to a similar extent. And we question Lane and Milesi-Ferretti's ranking of China as the more open economy. ${ }^{8}$ On balance, the capital opening task is bigger for China than for India.

Why has India been hitherto more financially open than China? The answer could lie in a mix of the need to fund current account deficits in India, the greater rigour with which the controls are enforced in China, the longstanding multinational operations of Indian private firms to arbitrage onshore and offshore markets (Subramanian 2009), and a larger footprint of global banks in the Indian domestic banking market. Future research could provide different explanations (Ma and McCauley 2013).

Whatever the cause of this longstanding difference, our evidence suggests China is rapidly eroding India's lead. As a policy intention, the paced internationalisation of the renminbi has no counterpart in India. By creating a pool of renminbi bank accounts and bonds outside the Chinese mainland and allowing for offshore delivery of the renminbi, this policy is also punching holes in the capital controls through which arbitrage transactions can pass. In fact, the renminbi internationalisation has been viewed by some as a part of the capital account liberalisation drive in China (Zhang 2014).

Third, an important conclusion of our study is, however, that on all three measures both the Chinese and the Indian economies have a way to go in terms of liberalising their capital accounts. Policy continues to segment onshore and offshore markets in both cases. More consistent opening movements lately in China may support its capital account liberalisation momentum.

8 We hope researchers will use these measures with greater care, even scepticism, and will look for new measures. The Chinn-Ito measure in particular is not clearly fit for the purpose to which it is often put. Moreover, there is little reason to think that 'the most finely gradated' (Quinn et al. 2011:492) measure of Schindler (2009) does not suffer from the same fundamental drawback. Looking at types of regulation does not reveal how restrictive they are, much less how restrictive they are in practice. De facto is the way to go. 
Fourth, while the consensus medium-term prospect is for an increase in net private external assets for China, our findings of onshore/offshore price gaps across three important financial markets point to potential pressure from large inward capital flows in the event of full capital opening. In particular, the renminbi and money-market instruments have been priced lower onshore than offshore, while the premium of onshore share prices of Chinese companies had disappeared by 2013. Indeed, the renminbi was among the most attractive carry-trade targets until the volatility around the latest trading-band widening in March 2014. The full implications of this greater flexibility remain to be seen. The longer end of the renminbi yield curve could also attract substantial inflows with current and prospective yields. Therefore, our price gap evidence raises questions about the dynamics and volatility of net private capital flows during the process of a full Chinese capital account liberalisation.

Chinese policymakers need to take into account the risks of such dynamics and volatility on the journey to capital account liberalisation. The contrast between possible short-term net inflows and projected medium-term net capital outflows upon liberalisation may amplify the potential volatility.

Initially large inward portfolio and banking flows could interact in unpredictable ways with existing imbalances in the domestic financial system. Financial imbalances can build up over the longer financial cycles that are not simply operating at business-cycle frequency (Drehmann et al. 2012). In China, the government-sponsored investment and credit boom of 2008-09 (which responded to the fallout from the boom-bust cycle in US real estate) has lifted credit in China well above its trend deepening vis-a-vis GDP. Total credit to the non-financial private sector as a ratio to GDP, including the fast-expanding shadow banking, rose by more than 60 per cent in the wake of the GFC, from below 120 per cent in 2007 to above 180 per cent in 2013. This could be a sign of increased financial vulnerability (Drehmann et al. 2012).

Financial imbalances and vulnerability could trigger capital outflows in a more liberal environment. In response of liberalisation of bank flows in a situation in which dollar rates remain low, chinese rates are tending higher and the exchange rate expectations show stability or an appreciation bias could be sizable. By the same token, a clear turn in the financial cycle in China, arguably in its late stages already, and the prospect of big credit losses in China, in combination with normalisation of US dollar rates, could risk a substantial private capital outflow from China. Such net private capital outflows would fundamentally differ from a desired and benign increase in the net Chinese private external claims on the rest of the world over the medium term. 
Under the circumstances, policymakers need to be concerned not only about the immediate money-market yield differential and its relation to exchange rate volatility, but also about the hard-to-predict outcome of the surge of credit in China. These considerations do not argue against incremental capital opening but at a minimum they argue for keeping a strong measurement system in place so that the authorities do not find themselves flying blind.

\section{References}

Aizenman, J. and Sengupta, R. (2011), The financial trilemma in China and a comparative analysis with India, November, Mimeo.

Baba, N. and Packer, F. (2009), 'Interpreting deviations from covered interest parity during the financial market turmoil of 2007-08', Journal of Banking and Finance 33(11):1953-62.

Bayoumi, T. and Ohnsorge, F. (2013), Do inflows or outflows dominate? Global implications of capital account liberalization in China, IMF Working Paper No. WP/13/189, International Monetary Fund, Washington, DC.

Chinn, M. and Ito, H. (2006), 'What matters for financial development? Capital controls, institutions, and interactions', Journal of Development Economics $81(1)$.

Chinn, M. and Ito, H. (2008), 'A new measure of financial openness', Journal of Comparative Policy Analysis 10(3):309-22.

Drehmann, M., Borio, C. and Tsatsaronis, K. (2012), Characterising the financial cycle: don't lose sight of the medium term!, BIS Working Papers No. 380, June, Bank for International Settlements, Basel.

Frankel, J. (1992), 'Measuring international capital mobility: a review', American Economic Review 82:197-202.

He, D., Cheung, L., Zhang, W. and Wu, T. (2012), 'How would capital account liberalization affect China's capital flows and the renminbi real exchange rates?', China and the World Economy 20(6):29-54.

He, D., Wang, H. and $\mathrm{Yu}, \mathrm{X}$. (2014), Interest rate determination in China: past, present, and future, February, Mimeo.

Hooley, J. (2013), 'Bringing down the Great Wall? Global implications of capital account liberalisation in China', Bank of England Quarterly Bulletin 53(4):304-16. 
International Monetary Fund (IMF) (2010), 'Measuring capital account restrictiveness: a survey of the literature', in Annual Report on Exchange Arrangements and Exchange Restrictions, pp. 48-51, Washington, DC: International Monetary Fund.

Kohli, R. (2011), India's experience in navigating the trilemma: do capital controls help?, Working Paper 257, Indian Council for Research on International Economic Relations, New Delhi.

Lane, P. and Milesi-Ferretti, G. (2003), 'International financial integration', IMF Staff Papers 50(Special Issue):82-113.

Lane, P. and Milesi-Ferretti, G. (2007), 'The external wealth of nations mark II: revised and extended estimates of foreign assets and liabilities, 1970-2004', Journal of International Economics 73(2):223-50.

Lane, P. and Schmuckler, S. (2007), 'International financial integration of China and India', in A. Winters and S. Yusuf (eds), Dancing with Giants: China, India, and the Global Economy, pp. 101-32, Singapore: The World Bank and Institute for Policy Studies.

Lasky, M. and Whalen, C. (2014), 'Economic growth is projected to be solid in the near term, but weakness in the labor market will probably persist', Congressional Budget Office Blog, 26 February.

Levy-Yeyati, E., Schmuckler, S. and Horen, N. (2009), 'International financial integration through the law of one price: the role of liquidity and capital controls', Journal of Financial Intermediation 18:432-63.

Liu, L.-G. and Otani, I. (2005), Capital controls and interest rate parity: evidence from China, 1999-2004, Presented to RIETI/BIS/BOC Conference on Globalization of Financial Services in China, March.

Ma, G. and McCauley, R. (2008a), 'Do China's capital controls still bind?', in B. Eichengreen, Y.-C. Park and C. Wyplosz (eds), China, Asia, and the New World Economy, pp. 312-40, Oxford: Oxford University Press.

Ma, G. and McCauley, R. (2008b), 'Efficacy of China's capital controls: evidence from price and flow data', Pacific Economic Review 13(1):104-23.

Ma, G. and McCauley, R. (2013), 'Is India or China financially more open?', Journal of International Money and Finance (39):6-27.

Ma, G. and McCauley, R. (2014), 'Global and euro imbalances: China and Germany', China and World Economy 22(1):1-29. 
Ma, G., Ho, C. and McCauley, R. (2004), 'The markets for non-deliverable forwards in Asia', BIS Quarterly Review (June):81-94.

McCauley, R., Shu, C. and Ma, G. (2014), 'Non-deliverable forwards: 2013 and beyond', BIS Quarterly Review (March):75-88.

McGuire, P. and von Peter, G. (2009), 'The US dollar shortage in global banking', BIS Quarterly Review (March):47-63.

Mancini, T. and Ranaldo, A. (2011), Limits to arbitrage during the crisis: funding liquidity constraints and covered interest parity, Ms, Swiss National Bank.

Misra, S. and Behera, H. (2006), 'Non-deliverable foreign exchange forward market: an overview', Reserve Bank of India Occasional Papers 27(3):25-55.

Ocampo, J. and Erten, B. (2014), Latin America's lessons from capital account liberalisation, March, Paper submitted to Pardee Task Force on Regulating Global Capital Flows, Global Economic Governance Initiative, Boston University.

Otani, I. and Tiwari, S. (1981), 'Capital controls and interest rate parity: the Japanese experience, 1978-81', IMF Staff Papers 28(4):793-815.

Peng, W., Miao, H. and Chow, N. (2008), 'Price convergence between duallisted A and H shares', in Macroeconomic Linkages between Hong Kong and Mainland China, H. Genberg and D. He (eds), pp. 295-315, Hong Kong: City University of Hong Kong.

Quinn, D., Schindler, M. and Toyoda, A. M. (2011), 'Assessing measures of financial openness and Integration', IMF Economic Review 59(3):488-522.

Reserve Bank of India (2006), Report of the Committee on Fuller Capital Account Convertibility [the Tarapore Report], July.

Schindler, M. (2009), 'Measuring financial integration: a new data set', IMF Staff Papers 56(1):222-38.

Subramanian, A. (2009), 'Discussion: resisting financial globalization in Asia', in Financial Globalization and Emerging Market Economies. Proceedings of an International Symposium Organised by the Bank of Thailand, Bangkok, 7-8 November 2008:223-6.

Zhang, M. (2014), Whether China should accelerate capital account liberalisation now?, Policy Discussion No. 2014.001, Chinese Academy of Social Science, Research Centre for International Finance. 
This text taken from Deepening reform for China's long-term growth and development, edited by Ligang Song, Ross Garnaut, Cai Fang, published July 2014 by ANU Press, The Australian National University, Canberra, Australia. 